\title{
Occupational Hazards and Safety of Sawmill Operators in Ogbese Ondo State, Nigeria
}

\author{
T. Akinbode ${ }^{1} \&$ J.O Owoeye ${ }^{1}$ \\ ${ }^{1}$ Department of Urban and Regional Planning, School of Environmental Technology, Federal University of \\ Technology, Akure, Nigeria \\ Correspondence: J.O Owoeye, School of Environmental Technology, Federal University of Technology, Akure \\ Nigeria. Tel: 234-0803-917-9250. E-mail: joowoeye@futa.edu.ng
}

Received: November 8, 2019 Accepted: December 2, 2019 Online Published: December 23, 2019

\begin{abstract}
This study examined the hazards and safety procedures adopted by sawmill operators in Ogbese, Ondo State, Nigeria. Data were collected through the administration of a set of structured questionnaire to examine the hazards associated with sawmill operators and safety practices adopted. Thirty (30) operators were purposively selected and administered with the questionnaire. Analysis was done using descriptive and correlation statistics. Findings, among others, revealed that sawmill operators do not have the required health safety gadgets needed to secure them from various hazards associated with their operations. Environmental pollutions, such as, smoke from burning sawdust, noise from heavy machinery in the industries, heavy trucks that carried sliced wood, solid and liquid wastes which caused nuisance to the environment posed serious health challenges to the operators and residents in the environment. The study proffered policy statements that could enhance the health and safety of sawmill operators and improve the environment.
\end{abstract}

Keywords: occupational hazards, sawmill operators, sliced wood, pollution, safety

\section{Introduction}

All over the world, industries have continued to contribute significantly to the development of humanity. Their establishment has brought about the dawn of civilization and consequently meets various human needs (Ugheoke, et al, 2006). Olaoye and Ajiboye (2013) state categorically that it has enhanced the quality of human life. As stated in Olawuni and Okunola (2014), industrial activities such as mining, manufacturing, transportation, sawmilling are important to the economy of a nation as they support and service rural activities and also provide employment opportunities for the general populace. One of those industries that provide sources of livelihood and economic base in cities and countries is sawmill industry. It is a wood based industry which produces one of the most important materials in the building and construction industry. The importance of the mill where these woods are processed and produced cannot be overemphasized. It is currently a notable employer of labour in the countries where they existed. They provide about $2 \%$ of the world's overall Gross Domestic Product (Jimoh, 2000). In developing countries, sawmill industry contributes an average of about $2.7 \%$ of GDP which keeps on increasing at a faster rate (Aina, 2006; Akinbode and Olujimi, 2014).

Sawmill represents an important economic force for development, particularly, in those developing countries with substantial endowment of forest resources. Sawmills have continued to service other wood-based industry locally and internationally without its effects on the employees and the adjoining residential area being adequately protected (Olujimi, 2011). In this regards, sawmill industry which is supposed to bring blessings to the nation in the area of GDP increase, creation of employment opportunities and offering many more advantages; but, in recent times, the disadvantages of the presence of industry outweigh the advantages as the health of the employees and residents around the wood processing industry are put under serious threat.

To a large extent, cases of environmental degradation remained traceable to the negligence and or ineptitude of professionals charged with the responsibility of ensuring that people have effective, efficient and unrestricted access to a safe, healthy and functional environment. Ideally, sawmill industry is not supposed to be sited within residential areas rather it ought to be located in a given zone, usually, at the outskirt of residential areas. In view of these observations, the thrust of this study is to examine the implication of sawmill activities on the health of operators and the safety procedure for residents in the adjoining environment. 


\section{Method}

\subsection{The Study Area}

Ogbese is an ancient village located in Akure North Local Government Area of Ondo State. It is located in the rain forest of the south-west of Nigeria, along Akure-Owo expressway. This makes it a natural destination of wood felled region of the state. Ogbese is located about $12 \mathrm{~km}$ away from Akure (the Ondo State Capital). It lies within latitudes $7^{0} 30^{1}$ and $7^{\circ} 45^{1}$ North of the Equator and Longitudes $5^{0} 45^{1}$ and $6^{0} 00^{1}$ East of the Greenwich Meridian. It shares political boundaries in the North by Ekiti State, South by Oke-Agunla, East by Uso in Owo Local Government and in the West by Bolorunduro. It covers a land area of about $5 \mathrm{~km}^{2}$ with an estimated population of 707 persons.

Ogbese has some distinctive topographic features in respect to its location. It is located on a rolling plain which slopes gently from the north towards Oke-Agunla settlement in the south. The eastern part is a gentle slope which spreads from Uso towards the town forming a V-shape at river Ogbese. The river flows from the north towards the south where it is used for various activities like fishing, irrigation, domestic consumption, industrial uses and rudimentary recreation. The area lies within the humid tropics. Hence, it experiences a hot-wet climate with annual mean sea level temperature of $27^{\circ} \mathrm{C}$. The total annual rainfall varies between $1500 \mathrm{~mm}$ and $2700 \mathrm{~mm}$, having double maxima occurrence in July and September which coincides with the passage of the overhead sun and short spell of August break lying in-between. The onset is characterized with both orographic and conventional types, accompanied by lightning and thunders with high relative humidity of about $80 \%$. The climate often experienced extreme cold weather in December and January.

The area exhibits an equatorial flora phenomenon in most parts until recently when traces of derived savannah are becoming noticeable due to human intervention in clearing, felling and burning. Indigenous trees found in the area include Iroko, Idigo, Oganwo, Mahogany, Olee, Oriro among others. These are intermingled with shorter trees and Oil palms in some open locations. As a matter of fact, savannah vegetation is fast overtaken and displacing the aborigine forest.

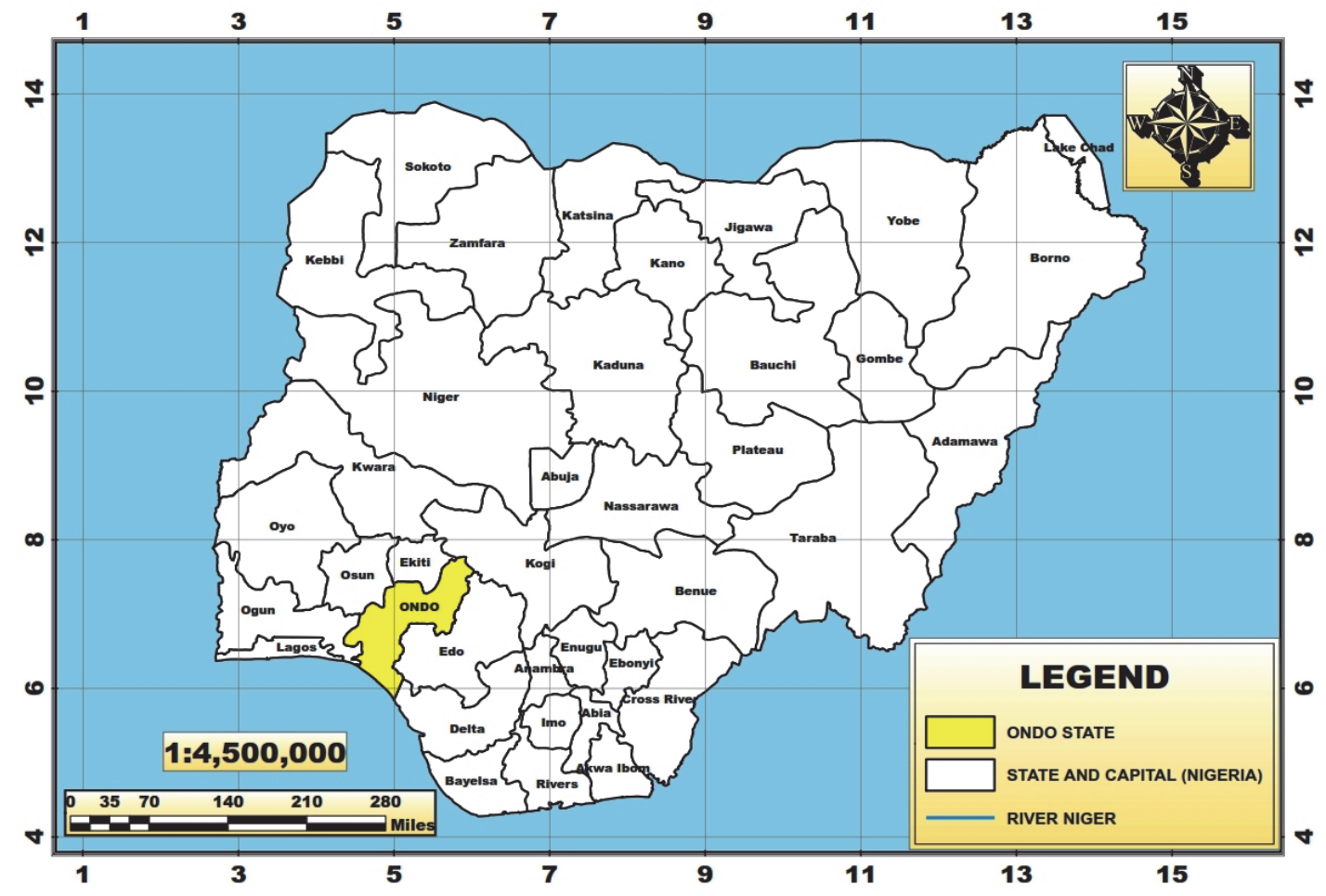

Figure 1. Ondo State in the National Setting

Source: GIS Plus Concept (2018).

Many of the inhabitants are non-native but migrants from different parts of the country with the Ibos having the greatest percentage. Most people come on daily basis from neighbouring towns and settlements like Owo, Uso and Akure to transact business. Greater percentage of the inhabitants engaged in lumbering and commercial activities. 
Only a few engaged in farming producing either cash or food crops like cocoa, kolanut, oil palm, yam, plantain, cocoyam, cassava, rice and vegetables. Palm wine tapping is equally noticeable as prominent economic activity in the area. Several other economic opportunities pervading the area have earned the people the privilege to venture into various activities that have made positive impact on their economy (ODSG, 2010).

Figure 2. The Study Area (Ogbese) in the Regional Setting

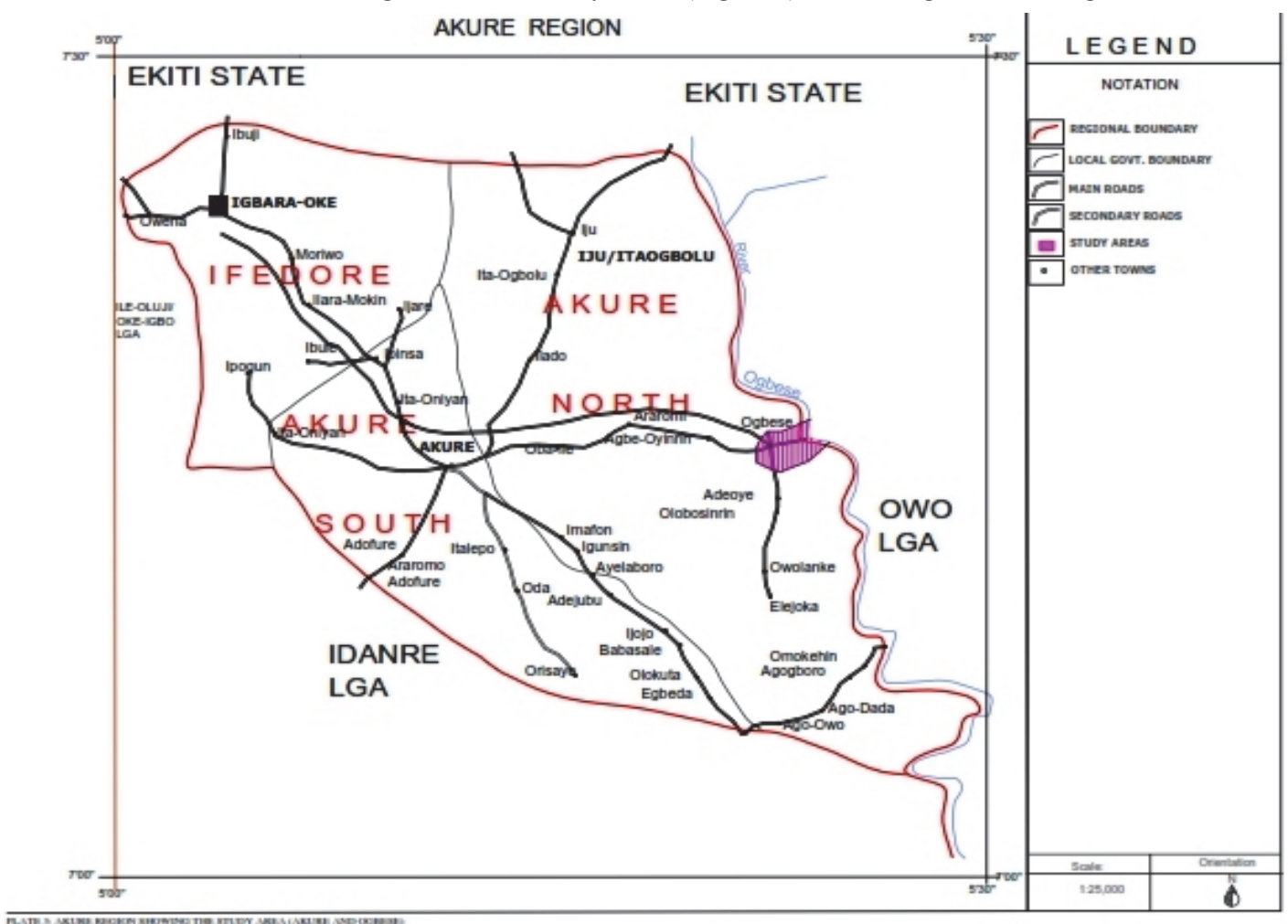

Source: Ondo State Ministry of Urban Development (Updated by Authors, 2018).

\subsection{The Data Base}

A set of well-structured questionnaire was administered to examine health hazards and safety practices adopted by the sawmill operators. Interview guides was used to obtain data from health workers within the study area. Photographs of scenery of interest were snapped coupled with personal observations. Variables addressed in the questionnaire include waste disposal method, health safety measures, income of respondents, among others. Modes of operation in sawmill factories in the study area are similar. As a result, fifty percent of the existing 30 sawmill factories were randomly selected as sample size for investigation. Existing sawmill factories were identified and grouped into two operating corridors - Ayede-Ogbese and Oke-odo Ogbese - which were used as basis for the selection of sawmill factories and operators used for the study as shown in Table 1.

Table 1. Distribution and Recovery of Questionnaire to Respondents in the Study Area

\begin{tabular}{lllllll}
\hline S/N & $\begin{array}{l}\text { Sawmill } \\
\text { Industrial } \\
\text { Corridors }\end{array}$ & $\begin{array}{l}\text { Existing } \\
\text { Sawmill } \\
\text { Factories }\end{array}$ & $\begin{array}{l}50 \% \\
\text { Sample } \\
\text { Size Taken }\end{array}$ & $\begin{array}{l}\text { Questionnaire } \\
\text { Distributed @ 2per } \\
\text { sawmill }\end{array}$ & $\begin{array}{l}\text { Questionnaire } \\
\text { Retrieved }\end{array}$ & $\begin{array}{l}\text { Percentage } \\
\text { Recovered }\end{array}$ \\
\hline 1. & $\begin{array}{l}\text { Ayede } \\
\text { Ogbese }\end{array}$ & -18 & 9 & 18 & 16 & 88.9 \\
2. & $\begin{array}{l}\text { Oke-Odo } \\
\text { Ogbese }\end{array}$ & 12 & 6 & 12 & 11 & 91.7 \\
& Total & 30 & 15 & 30 & 27 & 90.0 \\
\hline
\end{tabular}

Source: Authors' Research Design (2018).

In all, two sawmill operators were randomly picked in each of the selected sawmill factories for the administration 
of questionnaire knowing fully well that their activities are homogenous in nature. Okoko (2001) stipulates that sample size depends on variability of the population under study. In line with this, $50 \%$ of the sawmill factories in the study area was considered adequate for the study. Invariably, total sampled size of 15 sawmill operators was considered suitable for the study within the two identified sawmill industrial corridors.

Analysis of data was carried out using descriptive and inferential statistics. The descriptive method utilized tables, charts and pictorial illustrations while the inferential approach utilized the correlation analysis in testing the formulated hypothesis. Secondary data were obtained from textbooks, journals, conference and seminar papers, dissertations, internet, relevant ministries and establishments.

Table 2. Sampled Sawmill Industries in the study area

\begin{tabular}{llllll}
\hline S/N & $\begin{array}{l}\text { Sawmill Industrial } \\
\text { Corridors }\end{array}$ & $\begin{array}{l}\text { Existing } \\
\text { Sawmill }\end{array}$ & $\begin{array}{l}\text { Number } \\
\text { Sampled }\end{array}$ & $\begin{array}{l}\text { Names of Selected Sawmill } \\
\text { Factories in each corridor }\end{array}$ & $\begin{array}{l}\text { Percentage } \\
\text { Sampled }\end{array}$ \\
\hline 1 & Ayede Ogbese & 18 & 9 & $\begin{array}{l}\text { Australia Sawmill, Alayere, Elemo, } \\
\text { Ola-Abata, 09 Sawmill, Agbula, } \\
\text { Meens, Unifous, Kasimola. }\end{array}$ & 50.0 \\
2 & Oke-Odo Ogbese & 12 & 6 & $\begin{array}{l}\text { Eje-jesu, Mitor, Esan, Oyo, Titilope } \\
1 \text { and Archifer 2 }\end{array}$ & 50.0 \\
& & & & & 100.0 \\
\hline
\end{tabular}

\section{Source: Authors' Research Design (2018)}

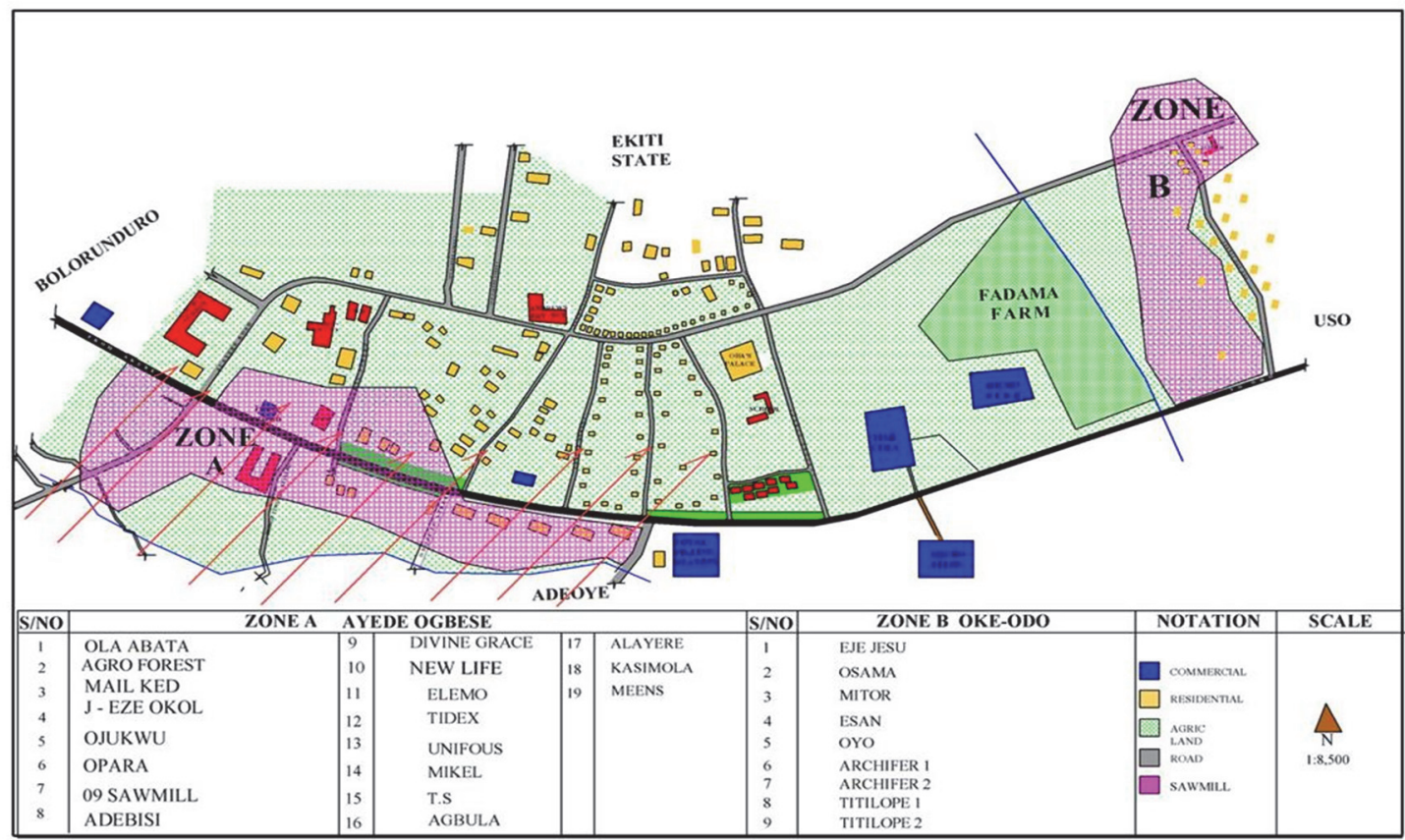

Figure 3. Map of Ogbese Showing the Sawmills

Source: Satellite Imagery (Updated by Authors, 2018).

\section{Results and Discussion}

\subsection{Socio-economic Status of Respondents}

This research revealed that most respondents had basic education with only $16.6 \%$ who do not have basic educational training. The breakdown in Table 3 revealed that there is significant literacy level among the respondents as greater percentage had acquired, at least, secondary school education. This implies that appreciable proportion of the operators interviewed must be aware of possible hazards associated with their occupation and are expected to take precautionary measure. 
Findings on sawmill employee's annual income distribution, as shown in Table 3, revealed that $40.1 \%$ of the respondents earned below $\$ 100,000$ per annum ( $\$ 360 / \$ 1)$. Sizeable proportion of the population were mostly low income earners and the responses received revealed that poverty was prevalent amongst the people. According to Fasakin (2000), the estimation of high density average occupancy ratio of 12 persons per room with the per capital income of an average number of $40.1 \%$ is to be accepted as very low. This is an indication that the prevailing socio-economic status of residents in the area is below the poverty line. This can be corroborated by the United Nation's declaration which put the approximated value of absolute poverty life below $\$ 1$ per day and relative poverty below $\$ 2$ per day. This situation, no doubt, determines people's standard of living, housing satus and requirement for good health care.

Table 3. Level of Education and Annual Income Status

\begin{tabular}{lll}
\hline Education Status & Frequency & Percentage \\
\hline No Formal Education & 5 & 16.6 \\
Primary & 6 & 20.1 \\
Secondary & 16 & 53.3 \\
Tertiary & 3 & 10.0 \\
Total & $\mathbf{3 0}$ & $\mathbf{1 0 0 . 0}$ \\
\hline Annual Income (\#) & Frequency & Percentage \\
\hline Below 100,000 & 12 & 40.1 \\
$100,001-300,000$ & 10 & 33.3 \\
$300,001-500,000$ & 5 & 16.6 \\
500,001 and Above & 3 & 10.0 \\
Total & $\mathbf{3 0}$ & $\mathbf{1 0 0 . 0}$ \\
\hline
\end{tabular}

$*$ As at $2018, \$ 1=\$ 480.00$

Source: Authors' Field Work (2018)

Information got from Town Planning office, as shown in Table 4, reveal that $23.3 \%$ of sawmills in the study area have no plan approvals. Sawmills that make up this $23.3 \%$ are the major ones constituting nuisance within the environment. They constitute environmental problems that threaten the lives of employees and residents within the area. They are characterized with inappropriate location and emission of hydrocarbon and poisonous gases that pollute the environment in the area.

Table 4. Operational Town Planning Approval Status of Sawmill in Akure

\begin{tabular}{lll}
\hline Approval Status & Frequency & Percentage \\
\hline Valid Planning Approval & 20 & 66.6 \\
Pending Planning Approval & 3 & 10.1 \\
No Approval & 7 & 23.3 \\
Total & 30 & 100 \\
\hline
\end{tabular}

Source: Authors' Field Work (2018).

\subsection{Health Related Issues among Sawmill operators in the Study Area}

Table 5 shows several ailments suffered by sawmill operators in Ogbese. From the table, $50 \%$ of the sampled respondents reported cases of skin diseases among their staff while $63.3 \%$ claimed of having cases of physical injuries sustained during their operations. The table also showed no cases of blindness was recorded among the staff in the sampled sawmill industries, $86.6 \%$ reported cases of body pains while $76.6 \%$ had cases of impaired earring. 
Table 5. Ill Health Ailments Suffered by Sawmill Operators during Wood Processing Activities

\begin{tabular}{lcc}
\hline Sickness & Frequency (30) & Percentage \\
\hline Respiratory Problems & 15 & 50 \\
Skin diseases & 15 & 50 \\
Physical Injuries & 17 & 63.3 \\
Blindness & NA & NA \\
Body pains & 26 & 86.6 \\
Deaf (earing Problem) & 23 & 76.6
\end{tabular}

Source: Authors' Field Work (2018).

In view of these observations, the available safety, health and environmental management (SHE) plans by the various sawmill factories in the study area were looked into. Findings revealed that only $26.6 \%$ of the sawmill factories possesses personal protective equipment (PPE). Table 6 reveals none availability of communication gadgets within the sawmill factories sampled in the study area. From the table, $36.6 \%$ of the sampled sawmill industries possessed first aid box for the use of their staffs in case of any minor accident. The table also reveal the level of environmental management plan (EMP) available in each sawmill industry.

Table 6. Available Safety, Health and Environmental (SHE) Plans in the Study Areas

\begin{tabular}{lll}
\hline SHE PLANS & Frequency (30) & Percentage \\
\hline Personal Protective Equipment (PPE) & 8 & 26.6 \\
Communication Gadget (CG) & NA & NA \\
First Aid Box & 11 & 36.6 \\
Environmental Management Plan (EMP) & NA & NA \\
\hline
\end{tabular}

*NA $=$ Not Available *SHP $\quad$ S Safety Health Equipment

\section{Source: Authors' Field Work (2018)}

Table 7 shows the various waste disposal methods available in the sawmill factories in the study area, and the result showed that none of these sawmills recycled their waste. However, $80 \%$ disposed their wastes through open site burning method within their premises as shown in Figure 4. All the sawmill factories made use of open space dumping with disorganized waste dump of sawdust, wood shavings, wood off-cuts and even the logs yet to be processed which provided breeding environment for worms, rodents and other insects like flies, crickets, bees, beetles, mosquitoes, among others, which accounted for the increasing incidences of malaria ailment among residents and workers in the study area.

Table 7. Waste Management Practices by Sawmill Industries in the study area

\begin{tabular}{lll}
\hline Mode of waste disposal & No. of Sawmill (15) & Percentage \% \\
\hline Re-use & NA & NA \\
On-site Burning & 12 & 80 \\
Open space dumping & 15 & 100 \\
Organized collection & 5 & 33.3 \\
\hline
\end{tabular}

Source: Authors' Field Work (2018). 


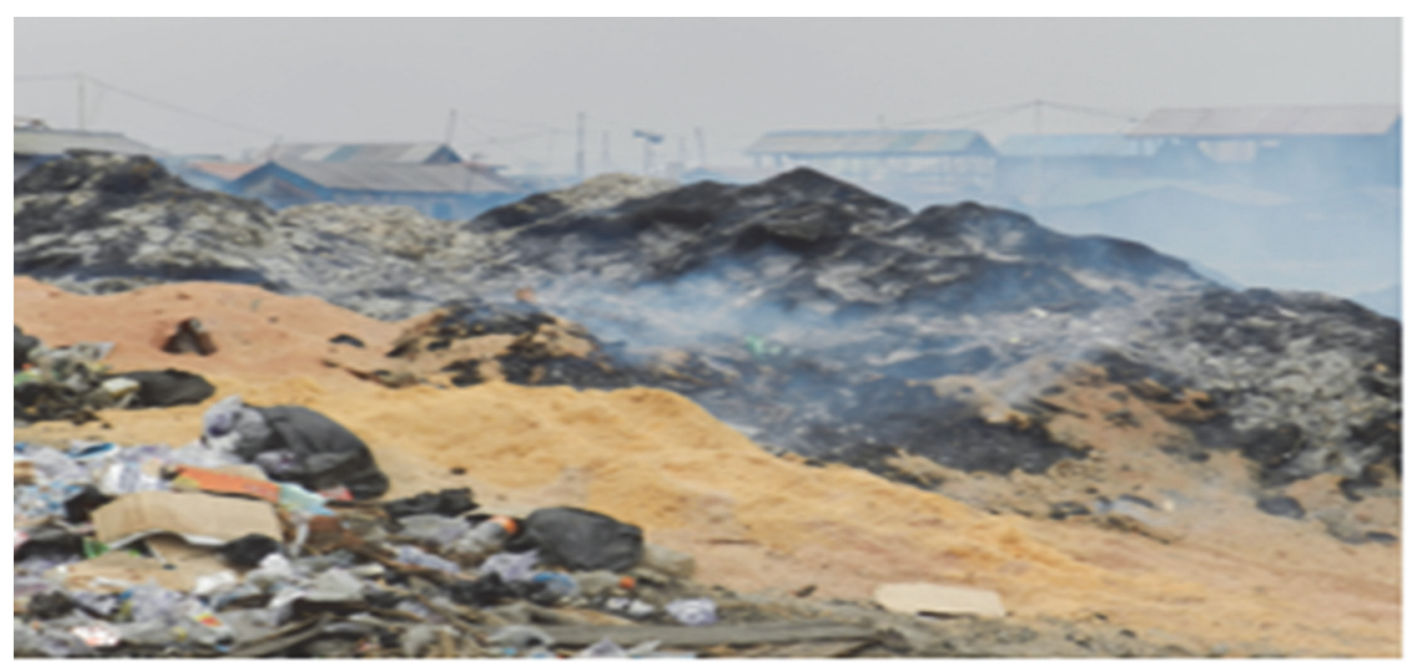

Figure 4. Burning of wastes at site as disposal method in all sawmills in Ogbese

Source: Authors' Field Survey (2018).

During operation and burning of sawmill wastes; sawdust generated, ashes and thick smokes are released into the air thereby produced air pollution which in-turn caused breathing problems and cancer related ailments. It also harms plants, animals, and the general ecosystems. Some air pollutants return to earth in the form of acid rain which corrodes roofs of buildings. The state of personal hygiene in sawmill industry is of much concern from the results of the correlation analysis conducted. The frequency of waste collection (FCOL) and frequency of waste disposal methods (FWDM) were correlated independently with environmentally induced diseases and the results are presented in Tables 8 and 9 .

Table 8. FCOL of waste versus prevalent diseases

\begin{tabular}{|c|c|c|}
\hline $\begin{array}{l}\text { Environmentally } \\
\text { induced diseases }\end{array}$ & $\begin{array}{ll}\text { Pearson } & \text { correlation } \\
\text { coefficient }(r) & \end{array}$ & $\begin{array}{l}\text { Approximate } \\
\text { significance }\end{array}$ \\
\hline FCOUGH & -.376 & $.000 *$ \\
\hline FCATARRH & -.354 & $.000 *$ \\
\hline FSKINFECT & -.313 & $.000 *$ \\
\hline FMALAR & -.270 & $.000 *$ \\
\hline FDYSENT & -.279 & $.000 *$ \\
\hline FTYPHOID & -.291 & $.000 *$ \\
\hline FWORMS & -.179 & $.006^{*}$ \\
\hline FACDIARR & -.253 & $.000 *$ \\
\hline FBDWEAK & -.179 & $.006 *$ \\
\hline FMEASL & -.192 & $.004 *$ \\
\hline FTUBER & -.177 & $.007 *$ \\
\hline FSLEEP & -.064 & .333 \\
\hline
\end{tabular}

FCOL $=$ Frequency of collection

* Correlation significance at 0.01 alpha levels

** Correlation significant at 0.05 alpha levels

Source: Authors' Field Work Analysis (2018)

There was inverse relationship between frequency of collection of waste and incidences of some environmentallyinduced diseases. According to the correlation coefficient data, the noticeable ones are Frequency of Cough 
(FCOUGH), Frequency of Catarrh (FCATARRH), Frequency of skin Infection (FSKINFECT), Frequency of Malaria (FMALAR), Frequency of Dysentery (FDYSENT), Frequency of Typhoid (FTYPHOID) and Frequency of acute Diarrhea (FACDIARR). But the most noticeable are FCOUGH, FCOLD and FSKINFECT with $r$ values of $-.376,-.354$ and -.313 . The inclusion of cold here may be as a result of the interconnections of the diseases.

Table 9. Management of Waste (MW) Versus Prevalent Diseases

\begin{tabular}{|c|c|c|}
\hline $\begin{array}{l}\text { Environmentally induced } \\
\text { diseases }\end{array}$ & $\begin{array}{ll}\text { Pearson } & \text { correlation } \\
\text { coefficient }(r) & \end{array}$ & $\begin{array}{l}\text { Approximate } \\
\text { significance }\end{array}$ \\
\hline FCOUGH & -.188 & $.004 *$ \\
\hline FCATARRH & -.190 & $.004 *$ \\
\hline FSKINFECT & -.064 & .332 \\
\hline FMALAR & -.309 & $.000 *$ \\
\hline FDYSENT & -.297 & $.000 *$ \\
\hline FTYPHOID & -.065 & .323 \\
\hline FWORMS & .002 & .980 \\
\hline FACDIARR & -.140 & $.033 * *$ \\
\hline FBDWEAK & -.191 & $.004 *$ \\
\hline FMEASL & -.163 & $.013 * *$ \\
\hline FTUBER & -.179 & $.006^{*}$ \\
\hline FSLEEP & -.243 & $.000 *$ \\
\hline
\end{tabular}

* Correlation significance at 0.01 alpha levels

** Correlation significant at 0.05 alpha levels

Source: Authors' Field Work Analysis, 2018.

The level of the interrelationship between the management of waste and the prevalence of diseases in the study area is shown in Table 9. From the table, the correlation value (r) for FMALAR is -.309 and significant at both 0.01 and 0.05 critical limits. This is justified by the fact that all the sawmill factories in the study area (100\%) engaged in Open Space Dumping which gave room for breeding of mosquitoes which is the carrier of malaria parasite. The Regression analysis of the likelihood effect of sawmill factories and environmental quality variables on health status, as presented in Tables 10, shows that there was interconnection between various diseases. The analysis shows how diseases are related and which one could lead to another. Although the detail interpretation of this requires the full knowledge of medicine, but mere looking at it, one can easily grasp the dimensions of environmentally-induced diseases presented in this study.

\subsection{Most Frequently Experienced Tragedy Often Caused by Sawmill Activities}

This study probed into the perception of the public on the frequency of tragedy often experience as a result of the activities of the sawmill factories. The summary is shown in Table 10. 
Table 10. Interconnectivity between Environmentally Induced Diseases

\begin{tabular}{|c|c|c|c|c|c|c|c|c|c|c|c|c|}
\hline & 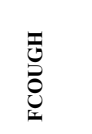 & $\stackrel{0}{0}$ & 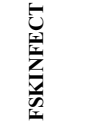 & 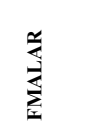 & 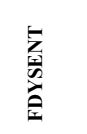 & 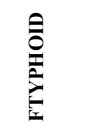 & 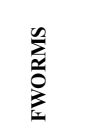 & 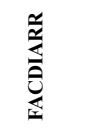 & 光 & $\sum_{i=1}^{\vec{n}}$ & 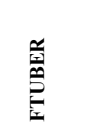 & 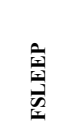 \\
\hline FCOUGH & 1 & $.874(* *)$ & $.723(* *)$ & $.787(* *)$ & $.739{ }^{(* *)}$ & $.524(* *)$ & $.303(* *)$ & $.463(* *)$ & $.548(* *)$ & $.348(* *)$ & $.347(* *)$ & $.414(* *)$ \\
\hline FCATARRH & $.874(* *)$ & 1 & $.734(* *)$ & $.801(* *)$ & $.753(* *)$ & $.542(* *)$ & $.401(* *)$ & $.498(* *)$ & $.581(* *)$ & $.371(* *)$ & $.372(* *)$ & $.428(* *)$ \\
\hline FSKINFECT & $.723(* *)$ & $.734(* *)$ & 1 & $.665(* *)$ & $.794(* *)$ & $.737(* *)$ & $.520(* *)$ & $.721(* *)$ & $.450(* *)$ & $.637(* *)$ & $.620(* *)$ & $.350(* *)$ \\
\hline FMALAR & $.787(* *)$ & $.801(* *)$ & $.665(* *)$ & 1 & $.803(* *)$ & $.512(* *)$ & $.423(* *)$ & $.503(* *)$ & $.661(* *)$ & $.409^{(* *)}$ & $.389(* *)$ & $.488(* *)$ \\
\hline FDYSENT & $.739(* *)$ & $.753(* *)$ & $.794(* *)$ & $.803(* *)$ & 1 & $.755(* *)$ & $.534(* *)$ & $.801(* *)$ & $.608(* *)$ & $.750(* *)$ & $.759\left(^{* *}\right)$ & $.488(* *)$ \\
\hline FTYPHOID & $.524(* *)$ & $.542\left({ }^{* *}\right)$ & $.737(* *)$ & $.512(* *)$ & $.755(* *)$ & 1 & $.498(* *)$ & $.828(* *)$ & $.387(* *)$ & $.754(* *)$ & $.758\left(^{* *}\right)$ & $.320(* *)$ \\
\hline FWORMS & $.303(* *)$ & $.401(* *)$ & $.520(* *)$ & $.423(* *)$ & $.534\left(^{* *}\right)$ & $.498(* *)$ & 1 & $.570(* *)$ & $.381\left({ }^{* *}\right)$ & $.534(* *)$ & $.522(* *)$ & $.288(* *)$ \\
\hline FACDIARR & $.463(* *)$ & $.498(* *)$ & $.721(* *)$ & $.503(* *)$ & $.801(* *)$ & $.828(* *)$ & $.570(* *)$ & 1 & $.380(* *)$ & $.906(* *)$ & $.908\left(^{* *}\right)$ & $.377(* *)$ \\
\hline FBDWEAK & $.548(* *)$ & $.581(* *)$ & $.450(* *)$ & $.661(* *)$ & $.608(* *)$ & $.387(* *)$ & $.381(* *)$ & $.380(* *)$ & 1 & $.268(* *)$ & $.266(* *)$ & $.542(* *)$ \\
\hline FMEASL & $.348(* *)$ & $.371(* *)$ & $.637(* *)$ & $.409(* *)$ & $.750(* *)$ & $.754(* *)$ & $.534(* *)$ & $.906(* *)$ & $.268(* *)$ & 1 & $.966(* *)$ & $.363(* *)$ \\
\hline FTUBER & $.347(* *)$ & $.372(* *)$ & $.620(* *)$ & $.389(* *)$ & $\left..7599^{* *}\right)$ & $.758(* *)$ & $.522(* *)$ & $.908(* *)$ & $.266(* *)$ & $.966(* *)$ & 1 & $.320(* *)$ \\
\hline FSLEEP & $.414(* *)$ & $.428(* *)$ & $.350(* *)$ & $.488(* *)$ & $.488\left({ }^{* *}\right)$ & $.320(* *)$ & $.288(* *)$ & $.377(* *)$ & $.542(* *)$ & $.363(* *)$ & $.320(* *)$ & 1 \\
\hline
\end{tabular}

* Correlation significance at 0.01 alpha levels

** Correlation significant at 0.05 alpha levels

Source: Authors' Fieldwork Analysis, 2018

As indicated in Table 11, majority of respondents (93.3\%) claimed sawmill trucks and Lorries engage in indiscriminate parking while $90 \%$ linked the frequent damage of road surfaces in the localities to the sawmill trucks used by the factories. However, 53.3\% expressed their concerned on the regular breakdown of trucks used in sawmills which often leads to unwarranted gridlock by hindering free-flow of traffic in the localities. Majority of sawmills were using mechanically faulty and dilapidated Lorries in hauling these logs which were characterized by overloading of logs. This situation exposed the operators, residents and other road-users in the localities to high vehicular risks of incessant accidents. Thus, 50\% indicated that these were responsible for the cause of vehicular accidents while $46.6 \%$ identified this as causes of traffic congestion that lead to waste of many hours by commuters in their localities.

Table 11. Frequently Experienced Tragedies caused by Sawmill Activities in the study area

\begin{tabular}{lll}
\hline Experience & Frequency & Percentage \\
\hline Indiscriminate parking of trucks/lorries & 28 & 93.3 \\
Frequent damage of road surface by heavy duty trucks/lorries & 27 & 90.0 \\
Breakdown of trucks/lorries & 16 & 53.3 \\
Accidents caused by trucks/lorries & 15 & 50.0 \\
Traffic congestion caused by trucks/lorries & 14 & 46.6 \\
\hline
\end{tabular}

Note: Respondent may choose more than one option

Source: Authors' Field Work, 2018 


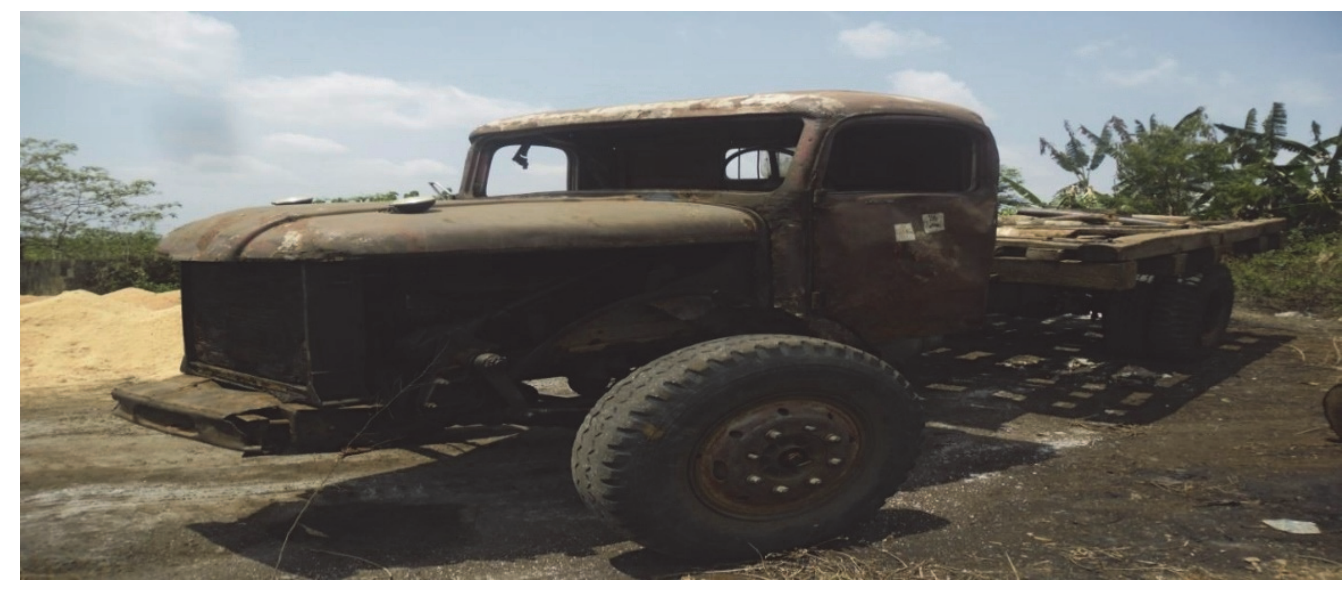

Figure 5. Sawmill Truck in state of disrepair

Source: Authors' Field Work, 2018.

Figure 5 shows the condition of trucks used by sawmill factories to convey their logs from the forest to the site. Most of the trucks are not road worthy and often pose danger to the operators and other road users. They often caused damage to drainage-channels, curvets, water pipe lines, electric poles and cables. They caused road congestions due to their inability to move faster.

The opinions of Town Planning Consultants in Ogbese zone were sought. They acknowledged being approached by individuals who were affected or feel concerned on health and safety risks such as noise and air pollution, unsanitary conditions, sawmill trucks which are not road worthy and other degraded situations that pose problems in or around their localities as a result of the activities of the sawmill factories. Such people are usually directed to the relevant environmental planning agencies. The physical development in the area had no master plan; consequently, developments are lopsided and done haphazardly. Thus, the quality of physical development in terms of housing conditions, landscape, environmental quality, infrastructure and social services in the area are rated "very low", compliance with approved plans and environmental planning standards "poor". Hence, the rising threat of pollution and contamination by the sawmill factories are on the increase. The general observation and physical appearance of the area does not give clear evidence or impact of the existence of physical planning in the study area.

\section{Conclusion}

In conclusion, the study revealed negative impact of sawmill operations on the health of workers and residents; particularly, noise pollution from their operation machines and other equipment. The machines were obsolete with most of the safety gadgets either removed or non-functional. Safety gadget and protective devices such as wearing of earmuff or plug when operating the machine, wearing of hand gloves when moving and stacking logs or sawn lumbers and environmental health aids equipment were not adequate, neither was there preventive measure given to other hazards like chemical emission from some species of log during operation.

Ineffective environmental management associated with the varied and multifaceted activities within the urban centre is causing environmental challenges that intimidate residents globally. These include the arbitrary locations of industries as well as discharges of hydrocarbon and toxic gases that are eating up the ozone layer which often results in climate change and global warming. Situations in the study area were never an exemption. In order to eliminate the associated health implications of sawmill activities in the study area, the study proffer some recommendations.

Government should establish cottage industries to make use of high volume of wastes generated from sawmill as raw materials. This cottage industry would be involved in the production of chipboards, particleboards or precast this sawdust into small sizes and sold to households as domestic fuel. Sawdust can also be used for composting biogenic wastes to produce excellent materials to improve soil fertility. All these would reduce the level of emissions resulting from open burning of waste materials and create new jobs in the cottage industries.

Noise pollution in the industrial area can be minimized to the barest minimum by adopting sustainable measures to mitigate possible hearing defects that may result from this. Short-term loans can be obtained by individual sawmill owners procure modern processing machines with protective gadgets and maintenance of their existing 
machine that would reduce the noise. Consequently, equipment and facilities operators should always be provided with protective shield and gloves when working in sawmill. First Aid Box stuck with drugs should be made available to carryout first aid services in case of any emergency.

Workers and the residents of the sawmill environment should be enlightened through regular seminars on the need for regularly medical checkup. The state and federal government should monitor sawmills through the environmental health officers in order to ascertain compliance with environmental condition that is conducive for working. Thus, sawmill owners should be compelled to register their workers with the National Health Insurance Scheme (NHIS) to make it more accessible and affordable. Regular seminar should be organized on how to protect their health and show concern for their workers.

Based on the various environmental problems identified in the study area, a long-term relocation plan of all sawmills outside the residential areas at the outskirt of the city by the state government in collaboration with the sawmill-owners should be embarked upon. This will go a long way to reducing the level of interference and impact of the health of residents.

\section{Acknowledgments}

The effort of our field assistants (Masters Kolawole Olatunji, Daodu Kola, and Adetolani Muriana) is well appreciated in their unwavering commitment in the collection of data used for this study.

\section{References}

Aina, O. M. (2006). Wood waste utilization for energy generation. Proceedings of the International Conference on Renewable Energy for Developing Countries. Retrieved August 1, 2009, from http//eere.edu/Aina.pdf

Akinbode, T., \& Olujimi, J. A. B. (2014). Effects of Sawmill Wastes in Residential Areas of Ogbese and Akure Townships, Ondo State, Nigeria. International Journal of Innovation and Scientific Research, 9(2), 399-409. Retrieved from http://www.ijisr.issr-journals.org/

Fasakin, J. O. (2000). Wiliness to Pay for the Services of Commercial Motorcycles in Akure, Nigeria. In Cities, 17(6), 447-452. https://doi.org/10.1016/S0264-2751(00)00042-1

Jimoh, H. I. (2000). Man-Environment Interactions. In Jimoh, H. I., \& I. P. Ifabiyi (Eds.), Contemporary Issues in Environmental studies. Ilorin: Haytee Press and Publishing Company.

Okoko, E. (2001). Quantitative Techniques in Urban Analysis: published by Kraft books limited, Ibadan.

Olaoye, T., \& Ajiboye, O. (2013). Management of occupational hazards in wood processing industries in SouthWest Nigeria.

Olawuni, P. O., \& Okunola, O. H. (2014). Socioeconomic Impacts of Sawmill Industry on Residents. A Case Study of Ile-Ife, Nigeria. Journal of Economics and Development Studies, 2(3), 167-176. http://dx.doi.org/10.15640/jeds.v2n3a12

Olujimi, J. A. B (2011). From Rural to Urban: The Nigerian Physical Planning Dilemma; $63^{\text {rd }}$ Inaugural Lecture Series at the Federal University of Technology, Akure (Delivered on $20^{\text {th }}$ Sept., 2011).

Ondo State Government (ODSG, 2010). ODSG News Watch Bulletin, September Edition p. 8.

Ugheoke, O. O., Balogun, D. O., Kaufmann, D. A., Ezigbo, K. U., \& Ubani, J. O. (2006). Tackling Environmental Problems for Sustainable Development in the Niger Delta". The Nigerian Environment Outreach Magazine; 1(1). Yenagoa, Bayelsa: The Environment Outreach.

\section{Copyrights}

Copyright for this article is retained by the author(s), with first publication rights granted to the journal.

This is an open-access article distributed under the terms and conditions of the Creative Commons Attribution license (http://creativecommons.org/licenses/by/4.0/). 